1960s" (237).

In clarifying this deeply complex history, clouded by the fissiparousness and ephemerality of most anarchist groups, Unruly Equality is undoubtedly a major achievement, and a contribution that is destined to become a standard history of anarchism in the United States. Yet while presenting itself as an intellectual history of anarchism, the extent to which Unruly Equality really adheres to the textual/contextual perspective that defines that historical sub-discipline is questionable. In one sense this is not a major criticism: to write a history that traces intellectual inheritances through a process of close textual analysis, focusing on the development of shared conceptual vocabularies, and undertaking the terminological archaeology this sometimes demands — while also appreciating the determining qualities of historical context - is probably impossible over such a broad timeframe, and in a work involving so many multifaceted characters. This fact becomes more apparent in the later stages of the book, where the aim shifts towards selecting those threads that most inform contemporary anarchist politics. Here, however, the fact that anarchism in the 1970s "was not a unified ... movement ... but an array of small groups excited by communalism, syndicalism, situationism, libertarian socialism, ultraleftism, revolutionary nonviolence, anarcha-feminism, and social ecology," will always inhibit the practical textual work that defines intellectual history (279).

To stress this criticism, however, would be to miss the real value of Unruly Equality. Its worth as an act of recovery, rescuing intrinsically interesting ideas and personalities from the condescension of posterity, to borrow E.P. Thompson's famous formulation, is without question. But Cornell also does not hide the fact that he sees the historical work at the heart of his book as having contemporary relevance, as the "wealth of experience and insight anarchists and their allies have accumulated throughout the twentieth century" are reassessed in the present (300). Perhaps, as the winter wind fluttering those banners gives way to spring and summer breezes, these ideas will never have been so important.

Matthew S. Adams Loughborough University, UK

\title{
Jude McCulloch and Dean Wilson, Pre-crime: Pre-emption, precaution, and the future (New York: Routledge, 2016). 154 pp. Paperback \$43.96.
}

McCulloch's and Wilson's book Pre-Crime is wonderfully paradoxical. It is a "history of the future" written in the present but, since its themes concern the prediction of future-crime and regard present security practices as the anxiety- provoking harbingers of ignominious things to come, its paradoxes become many as it points suggestively towards future dystopia. The authors warn that pre-crime "expands the risk of state crime, harm and injustice perpetrated in the name of security" (143). Early symptoms of the shift to pre-crime were observed more than a decade 
ago in the move from "detection" to "disruption" in the prevailing logic of police crime control (Innes and Sheptycki, "From Detection to Disruption: Intelligence and the Changing Logics of Police Crime Control in the United Kingdom," 2004). These authors attribute the consolidation of the pre-crime paradigm to Lucia Zeder's essay Pre-crime and Post-criminology?, published in 2007 (4). In this, the first book-length treatment of the subject, that argument is strengthened and hardened up. The authors suggest that such a strengthening and hardening is needed because "pre-crime is deepening and spreading as the gap between the ultimate harm targeted and the conduct that animates coercive interventions widens and more behaviors and groups are deemed threats warranting pre-emption" (5). The authors "define pre-crimes as substantive coercive state interventions targeted at non-imminent crimes" (5) and regard these control practices to be detrimental in at least two senses. First, by acting against predicted future crime, control agents actually produce the harmful situation that is the justification for their security actions. Secondly, the duplicity and double-think (my words) necessary in order for control agents to act on the so-called "pre-cautionary principle," undermines fundamental social values of trust, justice and fairness.

Of particular interest is the way that different legal instruments-including civil, administrative and criminal law ones_-are orchestrated by control agents in the manufacture of pre-crime cases (6). The authors observe "criminal law-like tools," in the hands of various security agents. One might add that rules are always tools in the hands of knowing social actors who rule with law (Bowling and Sheptycki, "Global policing and transnational rule with law," 2015). Global rule with law based on the pre-constructed hypothetical crimes was first manifest in pop-culture in Philip K. Dick's prescient short sci-fi story Minority Report, published in the febrile atmosphere of 1956 amidst the McCarthy-era witch-hunts and Cold War paranoia. The purpose of dystopian fiction writing is to forewarn and thereby deflect future developments. As the authors put it: "Pre-crime embraces a dark vision of the future by anticipating worst-case scenarios and acting as if they were foregone conclusions" (142). This is true of both the paradigm and the book, even if the concluding words of the latter insist that the future "is always contingent and depends on the values on which we base our decisions in the present" (143).

In contributing knowledge useful in deflecting the worst possible future, chapter six is a gem. It concerns the dividing line between evidence and intelligence in the orchestration of pre-crime policing (see especially 94-97). Conventional sociolegal debates about police accountability have traditionally focused on the criminal process and the production of evidence and the rules of disclosure. Intelligence represents a vast repository of information at the behest of security and control agents that is not subject to the same scrutiny as is evidence in a criminal trial and yet that information forms the basis for coercive action up to and including the use of lethal force. Shifting the accountability gaze towards the lack of transparency in the acquisition, analysis and actionability of intelligence in policing and security 
control is an important step in asserting civil liberty in contemporary times (Sheptycki, "The Police Intelligence Division of Labour," 2017, forthcoming).

As devotees of English history will undoubtedly note, the penchant for dexterous use of the law in upholding the avaricious claims of conquering authority has deep roots. For example, the reign of Henry VII was notable for the institution of the Court of Star Chamber and his plundering of the realm for the good of the sovereign, which set the stage for the opulent, womanizing and war-mongering years of the son, viz. Henry the VIII. This should serve to remind us that all history is the history of class struggle involving a venal, vicious and avaricious elite. The future history of pre-crime control is part of a present attempt to assert class domination (Sanders and Sheptycki, "Police, Policing and Stochastic Governance," 2016). Whether in magnificent Tudor garb, stubbornly attired in a business suit, garishly turned out in sleazy night-time fashion, or slackly dressed for the $19^{\text {th }}$ hole, the power elite governs with law when they have to and regardless of law when they can. It is striking that the urge to prevent future harm appears not to extend to such things as crimes against the environment, crimes of the military, financial and economic crimes in the banking system. In short, crimes of the powerful.

Except that they do. One could cite a voluminous criminological literature on all of the above mentioned topics and more. McCulloch's and Wilson's slim and perfectly formed book joins this literature, offering a disturbing consideration of the community of practice that makes up "counter-terrorism" — and it is criminal! Keeping in mind that awareness about the plight of the planet at the hands of piratical cut-throats is usually served up filtered through multi-channel mass media and that the resulting smokescreen of "truthiness" is only sustainable in the new social media available in the palm of one's hand, there is nothing like curling up with a good book. This is one of them.

James Sheptycki

McLaughlin College, York University

\section{William A. Pelz, A People's History of Modern Europe (London: Pluto Press, 2016). 256pp. Paperback $\$ 28.00$.}

William A. Pelz had an impossible task: how to digest 500 years of European history into 217 pages. Even more daunting, how to do it in a way that overturns traditional historical scholarship by making common, ordinary, everyday people the focus and lead actors of European society. "History is often written as if ruler, war leaders, and moneymakers are the only people in society or, at least, the only people who matter," Pelz writes in the Introduction. "It will be argued in this book that the common people matter and that their history matters" (viii). This is a noble, if elusive, goal. Unfortunately, this book largely ignores the common people. It simply adds a left-wing critique onto a traditional, even old-fashioned, snapshot of Euro- 